\title{
Investigation of Variation in Resistivity with depth in Parts of Imo River Basin, South-eastern Nigeria
}

\author{
Ikechukwu B. Ijeh \\ Department of Physics, Michael Okpara University of Agriculture, Umudike, P.M.B. 7267, Umuahia, Abia State \\ Nigeria
}

\begin{abstract}
Schlumberger configuration of electrical resistivity survey was used to obtain 88 vertical electrical sounding data from various locations in parts of Imo River Basin to determine the variation of resistivity of the subsurface at various depths. The resultant apparent resistivity values were processed to obtain the respective resistivities of the different layers and their layer thicknesses. The VES data were further processed with the Arch-View 3.2a GIS software to obtain Iso-Resistivity maps at different levels of sounding at the various points. Each map represents a slice of resistivity variation at the depth of investigation corresponding to $A B / 2=2 \mathrm{~m}$, $4 \mathrm{~m}, 10 \mathrm{~m}, 100 \mathrm{~m}, 200 \mathrm{~m}, 300 \mathrm{~m}$ respectively. The depths correspond to approximately $1.33 \mathrm{~m}, 2.67 \mathrm{~m}, 6.67 \mathrm{~m}$, $66.6 \mathrm{~m}, 133.3 \mathrm{~m}$ and $200 \mathrm{~m}$ respectively.
\end{abstract}

Keywords: Schlumberger configuration, electrical resistivity, GIS software, Iso-Resistivity maps

\section{Introduction}

Geophysical investigation is the most effective tool for indirectly mapping the subsurface rock formations and structures. A lot of problems connected with groundwater exploration can be solved with the help of geophysical methods. These include the location of water bearing formations and estimation of their depths and thicknesses; delineation of weathered zones, valley fills, freshwater- saline water interfaces, and groundwater flow directions[1]. Exploitation of this resource requires rapid and cost effective techniques of locating sustainable water bearing units (aquiferous zones) in a region (location of study area) where abortive boreholes are prevalent. Geophysical approach has, among others, been used to locate thesezoneswith great successes [2][3][4]..

There are five main methods of geophysical survey, namely: magnetic, gravity, seismic, electrical (self-potential, electromagnetic, resistivity and induced polarization) and well logging methods. Of these methods the electrical resistivity method is the most widely used method in groundwater research. This is due to the fact that the electrical properties, especially the resistivities, of geologic formations vary significantly between their dry and saturated states [5].

In vertical electrical sounding (VES) the goal is to observe the variation of resistivity with depth. The technique is best adapted to determining depth and resistivity for flat-lying layered rock structures, such as sedimentary beds, or the depth to the water table. The Schlumberger configuration is most commonly used for VES-investigations, where the current and potential pairs of electrodes have a common mid-point, but the distances between adjacent electrodes differ. The mid-point of the array is kept fixed while the distance between the current electrodes is progressively increased. This causes the current lines to penetrate ever greater depths, depending on the vertical distribution of conductivity [6].

Surface electrical resistivity surveying is based on the principle that the distribution of electrical potential in the ground around a current-carrying electrode depends on the electrical resistivities and distribution of the surrounding soils and rocks. The usual practice in the field is to apply an electrical direct current (DC) between two electrodes implanted in the ground and to measure the difference of potential between two additional electrodes that do not carry current. Usually, the potential electrodes are in line between the current electrodes, but in principle, they can be located anywhere. The current used is either direct current, commutated direct current (i.e., a square-wave alternating current), or AC of low frequency (typically about $20 \mathrm{~Hz}$ ). All analysis and interpretation are done on the basis of direct currents. The distribution of potential can be related theoretically to ground resistivities and their distribution for some simple cases, notably, the case of a horizontally stratified ground and the case of homogeneous masses separated by vertical planes (e.g., a vertical fault with a large throw or a vertical dike). For other kinds of resistivity distributions, interpretation is usually done by qualitative comparison of observed response with that of idealized hypothetical models or on the basis of empirical methods [7].

Mineral grains comprised of soils and rocks are essentially nonconductive, except in some exotic materials such as metallic ores, so the resistivity of soils and rocks is governed primarily by the amount of pore water, its resistivity, and the arrangement of the pores. To the extent that differences of lithology are accompanied by differences of resistivity, resistivity surveys can be useful in detecting bodies of anomalous 
materials or in estimating the depths of bedrock surfaces. In coarse, granular soils, the groundwater surface is generally marked by an abrupt change in water saturation and thus by a change of resistivity. In fine-grained soils, however, there may be no such resistivity change coinciding with a piezometric surface. Generally, since the resistivity of a soil or rock is controlled primarily by the pore water conditions, there are wide ranges in resistivity for any particular soil or rock type, and resistivity values cannot be directly interpreted in terms of soil type or lithology. Commonly, however, zones of distinctive resistivity can be associated with specific soil or rock units on the basis of local field or drill hole information, and resistivity surveys can be used profitably to extend field investigations into areas with very limited or nonexistent data. Also, resistivity surveys may be used as a reconnaissance method, to detect anomalies that can be further investigated by complementary geophysical methods and/or drill holes.

The electrical resistivity method has some inherent limitations that affect the resolution and accuracy that may be expected from it. Like all methods using measurements of a potential field, the value of a measurement obtained at any location represents a weighted average of the effects produced over a large volume of material, with the nearby portions contributing most heavily. This tends to produce smooth curves, which do not lend themselves to high resolution for interpretations. Another feature common to all potential field geophysical methods is that a particular distribution of potential at the ground surface does not generally have a unique interpretation. Although these limitations should be recognized, the non-uniqueness or ambiguity of the resistivity method is scarcely less than with the other geophysical methods. For these reasons, it is always advisable to use several complementary geophysical methods in an integrated exploration program rather than relying on a single exploration method.

\section{Geology Of The Study Area}

The study area is located between latitudes $5^{\circ} 05^{\prime \prime} \mathrm{N}$ and $5^{\circ} 45^{\prime \prime} \mathrm{N}$, and longitudes $7^{\circ} 00^{\prime \prime} \mathrm{E}$ and $7^{\circ} 30^{\prime \prime} \mathrm{E}$, within the Imo River Basin. This covers parts of four geologic formations in the Basin. These include the Coastal Plain Sands of the Benin Formation, Ogwashi-Asaba Formation, Bende-Ameki Formation, and Imo Shale. The location map of the study area is shown in Fig. 1. The Ogwashi-Asaba formation is subsumed within the coastal plain sands.

The Imo River Basin is based on a bedrock of a sequence of sedimentary rocks of about 5480m thick and with ages ranging from Upper Cretaceous to Recent [8]. The deposition of these sedimentary rocks is related to the opening of the South Atlantic Ocean and the formation of the rift-like Benue Trough of Nigeria in the Mesozoic (225-65 M.Y.B.P.) [9]. Generally, there are two different classes of formations underlying the Imo River Basin. About $80 \%$ of the basin consists in Coastal Plain Sand, which is composed of non-indurated sediments represented by the Benin and Ogwashi-Asaba Formations, and alluvial deposits at the estuary at the Southern end of the Imo River Basin. The remaining $20 \%$ is underlain by a series of sedimentary rock units that get younger southwestward, a direction that is parallel to the regional dip of the formations. The generalized regional stratigraphy is shown in Table 1.

Table 1: Generalized stratigraphy of the Imo River Basin [10].

\begin{tabular}{|l|l|l|l|}
\hline Age & $\begin{array}{l}\text { Formation } \\
\text { Name }\end{array}$ & $\begin{array}{l}\text { Maximum approx. } \\
\text { Thicknes }(\mathrm{m})\end{array}$ & Character \\
\hline $\begin{array}{l}\text { Miocene- } \\
\text { Recent }\end{array}$ & Benin & 2000 & $\begin{array}{l}\text { Unconsolidated, yellow and white sandstones, } \\
\text { occasionally pebbly with lenses of grey sandy } \\
\text { clay }\end{array}$ \\
\hline $\begin{array}{l}\text { Oligocene- } \\
\text { Miocene }\end{array}$ & $\begin{array}{l}\text { Ogwashi/ } \\
\text { Asaba }\end{array}$ & 500 & $\begin{array}{l}\text { Unconsolidated sandstones with carbonaceous } \\
\text { mudstones, sandy clays and lignite seams }\end{array}$ \\
\hline Eocene & Ameki & 1460 & $\begin{array}{l}\text { Sandstones; grey to green argillaceous } \\
\text { sandstones; shales and thin limestone units. }\end{array}$ \\
\hline Paleocene & Imo & 1200 & $\begin{array}{l}\text { Blue to dark grey shales and subordinate } \\
\text { sandstones. It includes two sandstones-the } \\
\text { Umuna and Ebenebe sandstones. }\end{array}$ \\
\hline
\end{tabular}




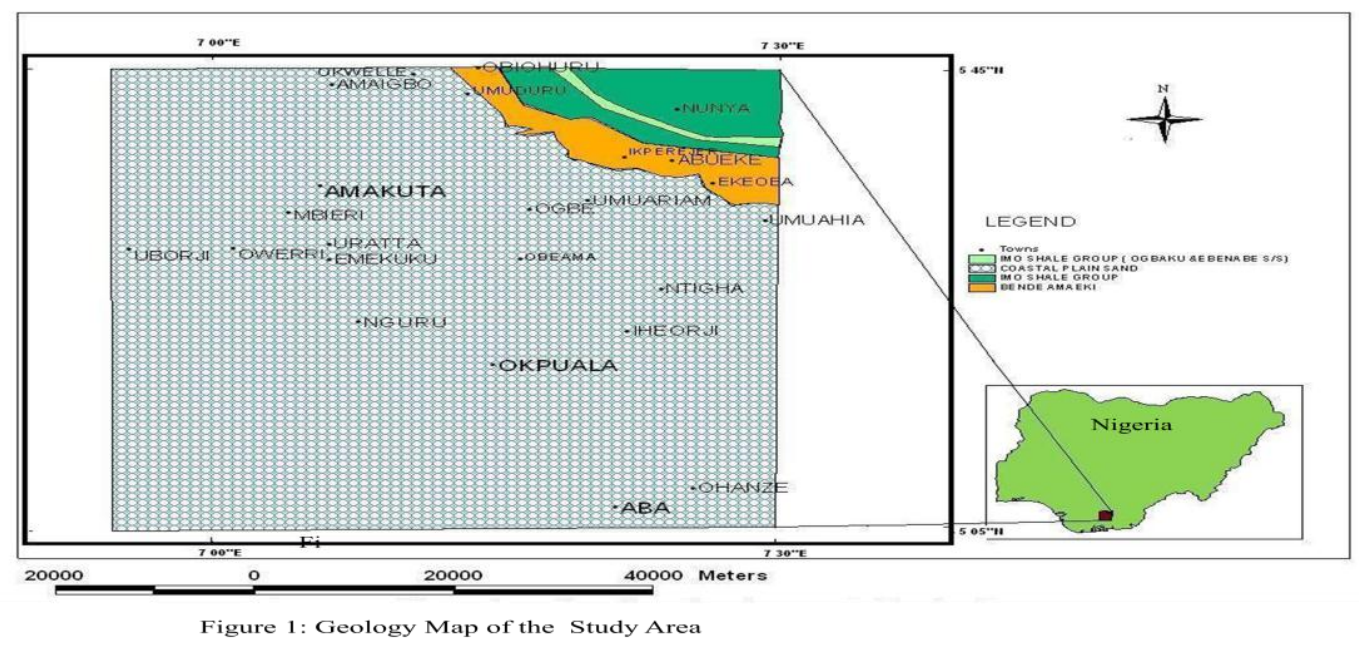

\section{Methodology}

The Schlumberger configuration was used in the resistivity survey. The ABEM Terrameter SAS 4000 was used to obtain VES data from the field. SAS stands for Signal Averaging System - a method whereby consecutive readings are taken automatically and the results are averaged continuously. The ABEM Terrameter SAS 4000 delivers high voltages and currents. In the resistivity surveying mode, the Terrameter SAS 4000 operates with a battery powered, deep-penetration resistivity meter with an output sufficient for a current electrode separation of 2000 meters under good surveying conditions. A maximum current electrode separation of $1000 \mathrm{~m}$ was used in this research. The SAS 4000 is equipped with a PC -compatible microcomputer and controlled by four knobs, and the results of measurements and calculations are digitally displayed on a liquid crystal display on its panel. The program allows the user to specify the measuring parameters in detail. A total of 88 VES data set were obtained in the various locations. Modeling of VES results was done using the RESIST software, which is an iterative inversion-modeling program. Analysis of the resulting apparent resistivity versus the half-current electrode separations yielded layered earth models composed of individual layers of specified thickness and apparent resistivity. The VES results, Table 1, were further processed with the Arch-View 3.2a GIS software to obtain Iso-Resistivity maps at different levels of sounding at the various points.

Table 1: Apparent Resistivity Values for Some Selected $A B / 2$ spreads.

\begin{tabular}{|c|c|c|c|c|c|c|c|c|c|c|c|c|c|}
\hline \multirow{3}{*}{$\begin{array}{l}\text { VES } \\
\text { NO }\end{array}$} & \multirow{3}{*}{$\begin{array}{l}\text { VES } \\
\text { STATION }\end{array}$} & \multicolumn{2}{|c|}{ COORDINATES } & \multirow{3}{*}{ 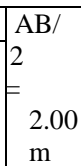 } & \multirow{3}{*}{ 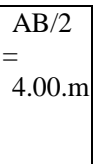 } & \multirow{3}{*}{$\begin{array}{l}\quad \mathrm{AB} / \\
2 \\
= \\
10.00 \mathrm{~m}\end{array}$} & \multirow{3}{*}{$\begin{array}{l}\mathrm{AB} / 2 \\
= \\
40.00 \mathrm{~m}\end{array}$} & \multirow{3}{*}{$\begin{aligned} & \mathrm{AB} / 2 \\
= & 60.00 \mathrm{~m}\end{aligned}$} & \multirow{3}{*}{$\begin{array}{l}\mathrm{AB} / 2 \\
=100 \mathrm{~m}\end{array}$} & \multirow{3}{*}{$\begin{array}{l}\mathrm{AB} / 2 \\
=150 \mathrm{~m}\end{array}$} & \multirow{3}{*}{$\begin{array}{l}\mathrm{AB} / 2 \\
= \\
200 \mathrm{~m}\end{array}$} & \multirow{3}{*}{$\begin{array}{l}\mathrm{AB} / 2 \\
= \\
250 \mathrm{~m}\end{array}$} & \multirow{3}{*}{$\begin{array}{l}\mathrm{AB} / 2 \\
= \\
300 \mathrm{~m}\end{array}$} \\
\hline & & $\begin{array}{l}\text { NORTH } \\
\text {-INGS }\end{array}$ & $\begin{array}{l}\text { EASTI- } \\
\text { NGS }\end{array}$ & & & & & & & & & & \\
\hline & & & & & & & & & & & & & \\
\hline KS1 & OKWELLE 1 & 192328 & 524631 & 1018 & 1069 & 496 & 699 & 967 & 1316 & 1668 & 1960 & 1979 & 1904 \\
\hline KS2 & OKWELLE 2 & 192101 & 525385 & 1377 & 869 & 1069 & 963 & 891 & 673 & 322 & 180 & 134 & 93 \\
\hline KS3 & UMUNNA 1 & 193625 & 527164 & 164 & 204 & 251 & 249 & 205 & 134 & 89 & 53 & 41 & 31 \\
\hline KS4 & OKWE 1 & 194011 & 528398 & 240 & 58 & 36 & 103 & 136 & 150 & 128 & 101 & 81 & 53 \\
\hline KS5 & OKWE 2 & 194534 & 529866 & 405 & 75 & 79 & 405 & 502 & 520 & 433 & 390 & 293 & 207 \\
\hline KS6 & OKWE 3 & 194887 & 531171 & 139 & 92 & 56 & 69 & 71 & 59 & 52 & 37 & 32 & 31 \\
\hline KS7 & UMUNNA 2 & 195957 & 532768 & 34 & 33 & 62 & 121 & 149 & 198 & 185 & 146 & 112 & 92 \\
\hline KS8 & AMURO 1 & 196535 & 533894 & 31 & 10 & 16 & 47 & 55 & 57 & 48 & 26 & 20 & 12 \\
\hline KS9 & AMURO 2 & 197628 & 535422 & 19 & 10 & 6 & 15 & 19 & 33 & 39 & 49 & 61 & 70 \\
\hline KS10 & UMUNNA 3 & 194590 & 532056 & 138 & 25 & 12 & 55 & 65 & 79 & 84 & 89 & 94 & 100 \\
\hline KS11 & OBIOHURU 1 & 193434 & 530967 & 338 & 125 & 218 & 930 & 1185 & 1821 & 1876 & 1624 & 1456 & 1210 \\
\hline KS12 & OBIOHURU 2 & 192063 & 530712 & 537 & 310 & 585 & 1210 & 1548 & 1727 & 1801 & 1469 & 1201 & 1002 \\
\hline KS13 & ORJI & 190453 & 530273 & 398 & 361 & 364 & 1402 & 2093 & 2960 & 3374 & 3519 & 3372 & 3061 \\
\hline KS14 & IKPEREJERE & 178912 & 545625 & 620 & 439 & 368 & 1277 & 2097 & 3265 & 4025 & 3811 & 3515 & 3232 \\
\hline KS15 & $\begin{array}{l}\text { UMUDIKE } \\
\text { ELUAMA }\end{array}$ & 178516 & 547311 & 1034 & 1456 & 2162 & 4311 & 5894 & 7081 & 6403 & 4670 & 3656 & 2843 \\
\hline KS16 & $\begin{array}{l}\text { UMUDIBIA } \\
\text { ELUAMA }\end{array}$ & 178555 & 548770 & 418 & 809 & 2025 & 7056 & 9365 & 11000 & 10225 & 8648 & 6395 & 4898 \\
\hline KS17 & ABUEKE & 178411 & 550335 & 1326 & 769 & 549 & 1080 & 1480 & 2100 & 1907 & 1529 & 1228 & 944 \\
\hline KS18 & EKEOBA & 174718 & 554389 & 1610 & 477 & 160 & 492 & 801 & 1328 & 1485 & 1954 & 1780 & 1519 \\
\hline KS19 & $\begin{array}{l}\text { AMAOGWU } \\
\text { G-WU }\end{array}$ & 176000 & 553668 & 8 & 10 & 22 & 39 & 24 & 14 & 9 & 5 & 4 & 3 \\
\hline KS20 & NUNYA 1 & 186622 & 550846 & 778 & 50 & 66 & 136 & 114 & 48 & 25 & 17 & 16 & 17 \\
\hline KS21 & NUNYA 2 & 187804 & 549394 & 271 & 221 & 531 & 571 & 496 & 364 & 271 & 197 & 155 & 119 \\
\hline KS22 & EZIAMA & 189225 & 530008 & 218 & 138 & 380 & 1388 & 1915 & 2801 & 2398 & 1878 & -- & -- \\
\hline
\end{tabular}


OSUAMA

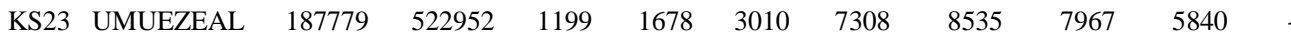
A UMUDURU

$\begin{array}{llllllllllllll}\text { KS24 UMUOKEHI } & 175472 & 557890 & 1890 & 1880 & 1840 & 1880 & 2740 & 2741 & 2000 & 2000 & 1900 & 1900\end{array}$

$\begin{array}{lllllllllllll}\text { KS25 } & \text { FAULKS RD, } 125638 & 544503 & 2330 & 1133 & 1542 & 1006 & 547 & 210 & 162 & 348 & 255 & 307\end{array}$ ABA

KS26 AFARAUKWU, UMUAHIA

KS27 OBOKWU NGURU,

KS28 UMU OLD UMUAHIA

KS29 UMUIKE LOWA

KS31 100 WORKS 168585 L/O OWERRI

OBOWO

KS33 UMUGHARA 167088 ONICHA

KS34 OBIBIEZENA $156051 \quad 511975$

KS35 NNARAMBI $168508 \quad 533985 \quad 508$ $\mathrm{A}$

KS36 OGBE

KS37 NKWO

$\begin{array}{llllllllllll}169345 & 535735 & 335 & 527 & 1138 & 3710 & 4990 & 7540 & 12120 & 18000 & 18870 & 17250\end{array}$ OBOHIA

$172246 \quad 530001 \quad 386 \quad 529$

KS38 UMUMBIR OPARANADI $\mathrm{M}$

KS39 UMUEZEAL 185305 A AMA UMUERIM

KS41 UMUARO UMUNUMO

KS42 UMUEZE

KS43 UMUANUNU 180934 NSU

KS44 UMUAGBA 168741540113 ONICHA

KS45 UMUDURU 15568 IKPEREJERE

KS46 UMUWIWU

UMUIHI
AMAOGU

$83186 \quad 532985-276$

$2793 \quad 3071$

3086

2390

1185

$440 \quad 238$

$164201 \quad 530389 \quad 1995$

1980

$1950 \quad 20$

$2400 \quad 2360$

2330

2505

3000

3100

313

2683

2435 AMAINYINT A

KS48 UMUCHOKO 173 AMACHARA

KS49 ABOH EBIKORO

84.959

$276 \quad 629$

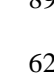




\begin{tabular}{|c|c|c|c|c|c|c|c|c|c|c|c|c|c|}
\hline & $\begin{array}{l}\text { UMUELEMA } \\
\text { I }\end{array}$ & & & & & & & & & & & & \\
\hline KS59 & $\begin{array}{l}\text { UMULUWE } \\
\text { AJIRIJA }\end{array}$ & 183344 & 534036 & 515 & 1124 & 1663 & 2694 & 3585 & 4569 & 3662 & 10268 & 4438 & 7287 \\
\hline KS60 & $\begin{array}{l}\text { UMUODIMO } \\
\text { DU ORODO }\end{array}$ & 180641 & 507501 & 1161 & 1411 & 1182 & 2231 & 2953 & 4318 & 5029 & 5534 & 5572 & 4540 \\
\hline KS61 & $\begin{array}{l}\text { UMUOHIAG } \\
\text { U }\end{array}$ & 157988 & 523336 & 3080 & 3050 & 3010 & 1880 & 1630 & 1600 & 1625 & 1550 & 2000 & 2858 \\
\hline KS62 & OKWUDOR & 191639 & 506091 & 769 & 1034 & 728 & 1654 & 2243 & 3261 & 4000 & 4235 & 4776 & 4155 \\
\hline KS63 & $\begin{array}{l}\text { UMUOMA } \\
\text { AMUCHA }\end{array}$ & 184724 & 506177 & 1439 & 1809 & 1972 & 3006 & 3962 & 4557 & 5318 & 5956 & 6647 & 4445 \\
\hline KS64 & $\begin{array}{l}\text { OFEIYI } \\
\text { UMUDI }\end{array}$ & 193219 & 517154 & 1990 & 1970 & 1940 & 1980 & 2840 & 2850 & 2880 & 2445 & 1970 & 1960 \\
\hline KS65 & $\begin{array}{l}\text { OBINUHU } \\
\text { NKWERRE }\end{array}$ & 195019 & 516680 & 138 & 273 & 2169 & 3060 & 2062 & 659 & 88 & 90 & 356 & 825 \\
\hline KS66 & $\begin{array}{l}\text { UMUGARA } \\
\text { NKWERRE }\end{array}$ & 190358 & 519088 & 2800 & 1359 & 1420 & 748 & 487 & 233 & 166 & 374 & 337 & 236 \\
\hline KS67 & $\begin{array}{l}\text { DURUEZE, } \\
\text { UMUOZU }\end{array}$ & 190104 & 519188 & 3114 & 4573 & 5666 & 3890 & 4389 & 3140 & 2348 & 2013 & 1780 & 1093 \\
\hline KS68 & $\begin{array}{l}\text { UMUDIWEB } \\
\text { UUMUOPAR } \\
\text { ADIM }\end{array}$ & 187611 & 520830 & 1570 & 3693 & 5620 & 3152 & 2651 & 3091 & 5624 & 8385 & 7515 & 6071 \\
\hline KS69 & ABBA & 185453 & 520014 & 3650 & 3700 & 3750 & 4590 & 3783 & 3150 & 3450 & 3050 & 2600 & 2740 \\
\hline KS70 & $\begin{array}{l}\text { UMUANYA- } \\
\text { AMAIGBO }\end{array}$ & 190967 & 518068 & 217 & 319 & 544 & 805 & 1097 & 1078 & 1050 & 1094 & 1435 & 1582 \\
\hline KS71 & $\begin{array}{l}\text { UMULEKE- } \\
\text { AMAIGBO }\end{array}$ & 190500 & 516223 & 1604 & 2954 & 3095 & 3289 & 4036 & 5897 & 4818 & 3905 & 2932 & 1985 \\
\hline KS72 & UMUOZU & 190358 & 519088 & 505 & 658 & 849 & 2140 & 2210 & 3686 & 3303 & 3262 & 3451 & 2759 \\
\hline KS73 & ABAJAH & 185587 & 519930 & 1763 & 2140 & 1028 & 499 & 887 & 643 & 742 & 789 & 2280 & -- \\
\hline KS74 & $\begin{array}{l}\text { AVUTU- } \\
\text { OBOWO }\end{array}$ & 173737 & 545627 & 2819 & $\begin{array}{l}1148 \\
4\end{array}$ & $\begin{array}{l}1323 \\
5\end{array}$ & 4708 & 3113 & 2926 & 3277 & 2273 & 1429 & -- \\
\hline KS75 & UMUARIAM & 171948 & 541939 & 282 & 790 & 1959 & 2420 & 1899 & 4499 & 6759 & 2937 & 3327 & 4032 \\
\hline KS76 & OTOKO & 171688 & 540042 & 1238 & 2683 & 2354 & 2570 & 1040 & 575 & 601 & 569 & 334 & -- \\
\hline KS77 & $\begin{array}{l}\text { AFOR } \\
\text { UMUOKEH }\end{array}$ & 173968 & 545263 & 878 & 1094 & 3704 & 6854 & 2263 & 2140 & 1284 & 6385 & 7740 & -- \\
\hline KS78 & $\begin{array}{l}\text { OKWELLE- } \\
\text { OJIAMA }\end{array}$ & 193261 & 524620 & 615 & 1015 & 1724 & 2223 & 2096 & 2811 & 1907 & 2099 & 1616 & 344 \\
\hline KS79 & OKWE & 194354 & 529340 & 126 & 192 & 255 & 331 & 269 & 31 & 102 & 402 & 39 & 98 \\
\hline KS80 & $\begin{array}{l}\text { NKWO- } \\
\text { UMUCHEKE }\end{array}$ & 195362 & 529032 & 293 & 282 & 398 & 795 & 373 & 214 & 165 & 166 & 144 & -- \\
\hline KS81 & $\begin{array}{l}\text { UMOKO- } \\
\text { OKWELLE }\end{array}$ & 192974 & 524741 & 987 & 2332 & 904 & 348 & 178 & 168 & 174 & 103 & 97 & 142 \\
\hline KS82 & $\begin{array}{l}\text { AMANO- } \\
\text { UMUAGWO }\end{array}$ & 193029 & 525879 & 1136 & 1500 & 2221 & 852 & 181 & 36 & 25 & 21 & 9 & 6 \\
\hline KS83 & $\begin{array}{l}\text { OKWE LGA } \\
\text { HQTRS }\end{array}$ & 196579 & 528827 & 2500 & 2520 & 2970 & 3160 & 2870 & 2980 & 2950 & 2380 & 2080 & 2150 \\
\hline KS84 & $\begin{array}{l}\text { UMUEZEAL } \\
\text { A-UMUNA }\end{array}$ & 196870 & 534218 & 189 & 205 & 118 & 11 & 10 & 10 & 10 & 6 & 5 & 5 \\
\hline KS85 & $\begin{array}{l}\text { AFOR- } \\
\text { EZIUHU, } \\
\text { UMUNA }\end{array}$ & 195102 & 532555 & 2475 & 2390 & 2340 & 3450 & 2690 & 2650 & 2650 & 1985 & 1970 & 2110 \\
\hline KS86 & $\begin{array}{l}\text { UMUDIMOH } \\
\text { A-AMAIKE }\end{array}$ & 194721 & 511981 & 1995 & 2534 & 2345 & 5454 & 4018 & 3809 & 3024 & 4030 & 3032 & 2963 \\
\hline KS87 & $\begin{array}{l}\text { AMANATOR } \\
\text {-IHITTE, }\end{array}$ & 195531 & 511394 & 428 & 557 & 336 & 23 & 1 & 4 & 9 & 73 & 131 & -- \\
\hline KS88 & AMIKE & 195053 & 512092 & 85 & 143 & 204 & 362 & 442 & 491 & 417 & 345 & 161 & 151 \\
\hline KS89 & $\begin{array}{l}\text { UMUEZE- } \\
\text { AMIKE }\end{array}$ & 195163 & 512203 & 168 & 269 & 511 & 1150 & 1387 & 2282 & 2829 & 3229 & 3403 & 3212 \\
\hline KS90 & NAZE & 159633 & 512175 & 473 & 592 & 628 & 1634 & 2150 & 2207 & 2475 & 2212 & 2148 & 2116 \\
\hline
\end{tabular}

\section{Results And Discussion}

Maps of the respective AB/2 spreads are shown in Figures 2, 3, 4, 5, 6 and 7 respectively. Each map represents a slice of resistivity variation at the depth of investigation corresponding to $A B / 2=2 \mathrm{~m}, 4 \mathrm{~m}, 10 \mathrm{~m}$, $100 \mathrm{~m}, 200 \mathrm{~m}, 300 \mathrm{~m}$ respectively. The depths correspond to approximately $1.33 \mathrm{~m}, 2.67 \mathrm{~m}, 6.67 \mathrm{~m}, 66.67 \mathrm{~m}$, $133.33 \mathrm{~m}$ and $200 \mathrm{~m}$ respectively. These have been assumed to be two thirds of $\mathrm{AB} / 2$. The maps were derived from data in Table 1 which shows the apparent resistivity values for selected $\mathrm{AB} / 2$ spreads above.

The map for $\mathrm{AB} / 2=2 \mathrm{~m}$ indicates lower values of resistivity $(0-991 \Omega \mathrm{m})$ around the parts of the study area within the Imo Shale, covering Amuro (KS 9), Umuna (KS 7), Nunya (KS 21); also, parts of the Ameki geologic formation covering Obiohuru (KS 12), Orji (KS 13), Ikperejere (KS 14), Abueke (KS 17). The areas shaded red have predominantly lower resistivities. The values of resistivity in areas within the Imo Shale are closer to the lower limit within this range, while the values of resistivity around Owerri are closer to the upper 
limit. The values of resistivity around Umuahia are also within this range, although they are closer to the middle and upper limit than the lower limit. This agrees with the geology of the area. At a low depth corresponding to $\mathrm{AB} / 2=2 \mathrm{~m}$ the formation is mainly low resistivity clay and shale. Imo Shale consists mostly of shale and some clay, with intercalations of standstone. Areas around Owerri fall within the coastal plain stands with generally higher resistivities.

There are locations that feature higher resistivity values such as Umuagba - Onicha (KS 44), Umueze (KS 42), Umuohiagu (KS 61). They are all located within the coastal plain sands. Fig. 2 shows the IsoResistivity map for $\mathrm{AB} / 2=2.00 \mathrm{~m}$. It represents the resistivity pattern at a depth of $1.33 \mathrm{~m}$. This gives an indication of the nature of the resistivity of the top soil in the study area. Fig. 3 shows the Iso-resistivity map at $\mathrm{AB} / 2=4.00 \mathrm{~m}$, which corresponds to the resistivity pattern at a depth of $2.67 \mathrm{~m}$. Higher resistivities can be observed at some locations between Nnarambia and Umuahia in Ogwashi-Asaba formation.

There is a noticeable shift in the spatial variation of resistivity for $A B / 2=10 \mathrm{~m}$ (Fig. 4). This is obvious from the fact that at greater depths the resistivity variation is different. Comparing the maps for $A B / 2=2 \mathrm{~m}$ and $\mathrm{AB} / 2=10 \mathrm{~m}$ it can be seen that for Owerri and Umuahia the resistivity increases. The Iso-Resistivity map for $\mathrm{AB} / 2=10 \mathrm{~m}$ is shown in Fig. 4, which corresponds to the resistivity pattern at a depth of $2.67 \mathrm{~m}$. The shift in resistivity is clearly seen in the two maps from 2000 to $2500 \Omega \mathrm{m}$. The increasing trend in resistivity with depth can be explained by the fact that at shallow depth in most of the areas we have clay and shale streaks and sandy shales or sandy clay. The area corresponding to Imo Shale and some parts of Ameki Formations feature the lowest resistivities, which indicate the presence of clay or shale $(<500 \Omega \mathrm{m})$. Areas with resistivities 500-1000 $\Omega \mathrm{m}$ could be interpreted as sandy clay for lower depth; or sandy shale at greater depth. Areas with resistivities 2000-8000 $\Omega \mathrm{m}$ could be interpreted as sand. Based on this, we can see from the iso-resistivity maps that areas south of Nnarambia which fall within the Benin Formation are largely sandy. The highest resistivities are located within the Ogwashi-Asaba Formations, particularly between Nnarambia (KS35) and Avutu-Obowo (KS75), and also between KS75 and KS26 (Umuahia). According to the geology of the area, Ogwashi-Asaba is characterized by unconsolidated sandstones with carbonaceous mudstones, sandy clays and lignite seams.

For $\mathrm{AB} / 2=100 \mathrm{~m}$ there is a location that features a marked increase in resistivity, at Nkwo Obohia (KS 37). There is a general indication of an increase of resistivity with depth. Fig. 5 shows the Iso- Resistivity map for $\mathrm{AB} / 2=100 \mathrm{~m}$, which corresponds to the resistivity pattern at a depth of $66.67 \mathrm{~m}$.

Fig. 6 shows the Iso-resistivity map for $A B / 2=200 \mathrm{~m}$. This represents the resistivity pattern at a depth of about $133 \mathrm{~m}$. The map shows that at the depth represented, areas with the highest resistivity are located within the middle of the study area, around the KS37 in the Ogwashi Asaba Formation. This implies that most of the sandstones are located around there since the resistivity range $>10542 \Omega \mathrm{m}$ are around it. There is also an indication that much of the areas within the Benin Formation from the middle down are mainly sands and sandstones.

Figure 7 shows the Iso-Resistivity map for $A B / 2=300 \mathrm{~m}$, representing a depth of about $200 \mathrm{~m}$. The very high resistivity at KS37 is also evident here. The Benin Formation features mainly sand and pebbly sandstones.

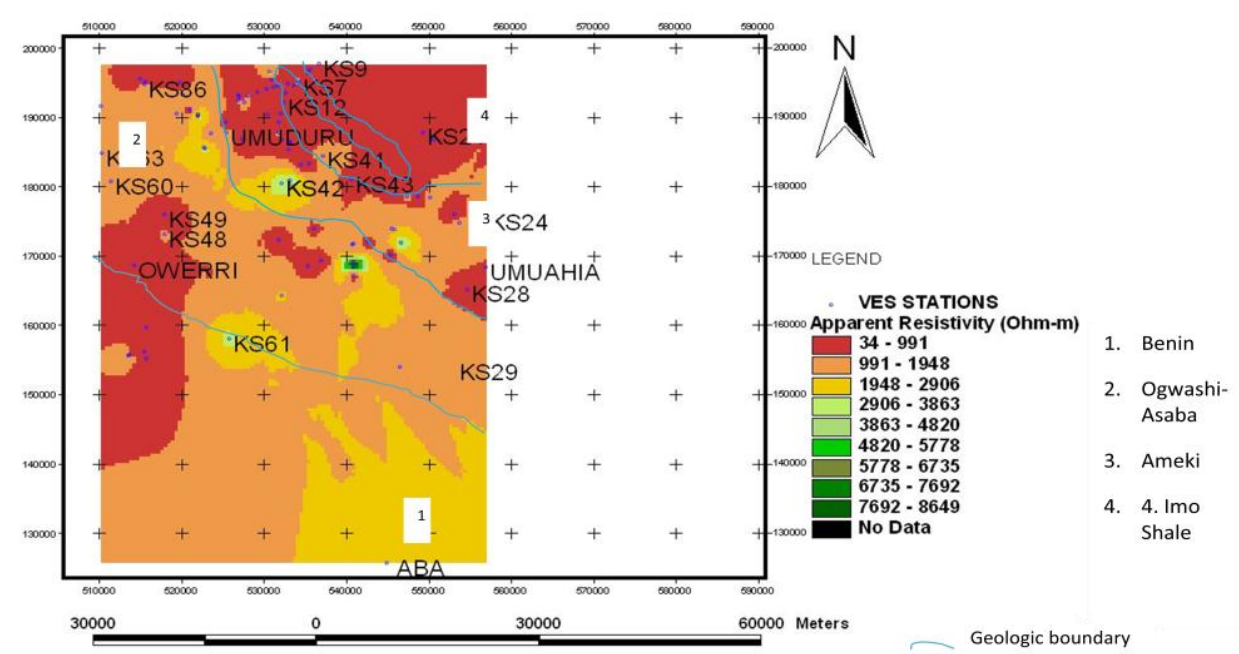

Figure 2: Iso-Resistivity Map for $\mathrm{AB} / 2=2.00 \mathrm{~m}$ 

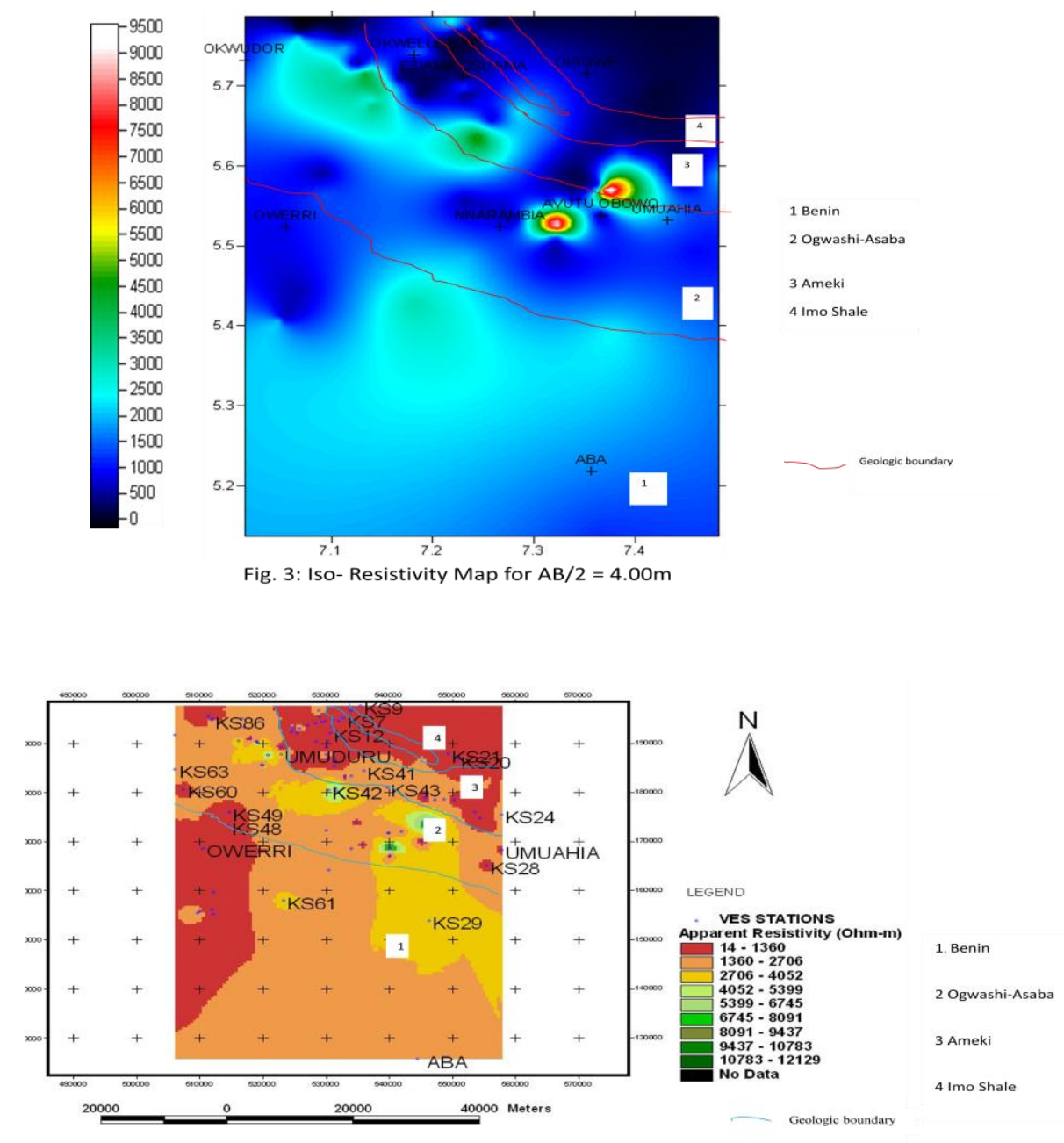

Figure 4: Iso-Resistivity Map for $\mathrm{AB} / 2=10.00 \mathrm{~m}$

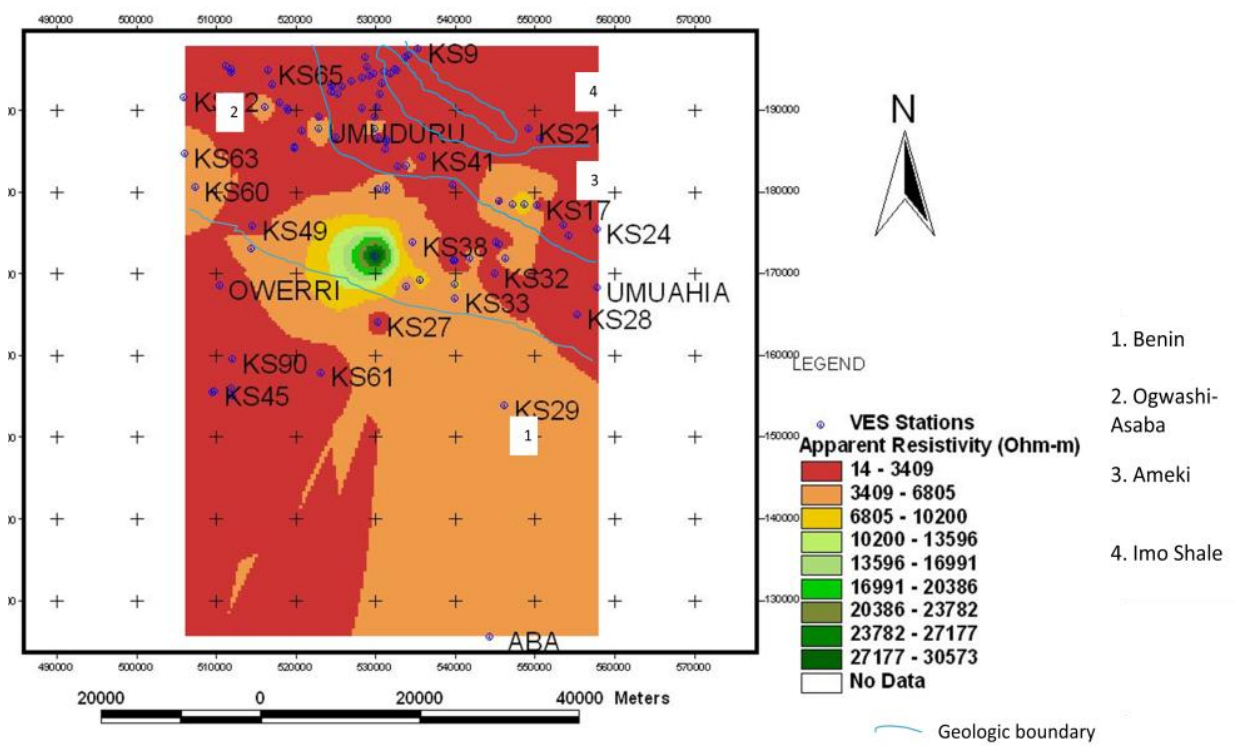

Figure 5: Iso-Resistivity Map for $\mathrm{AB} / 2=100.00 \mathrm{~m}$ 


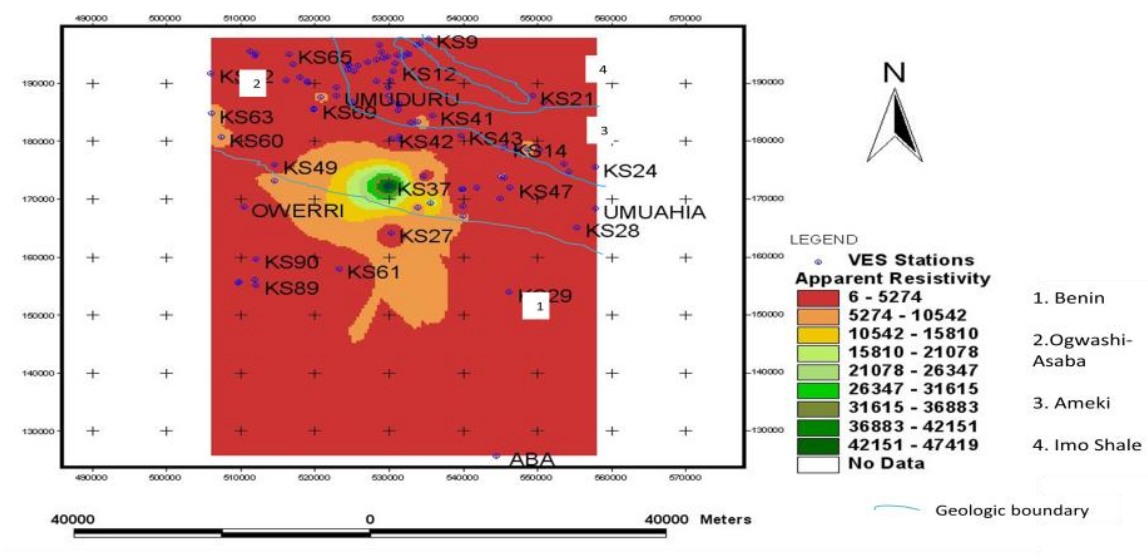

Figure 6: Iso- Resistivity Map for $\mathrm{AB} / 2=200.00 \mathrm{~m}$

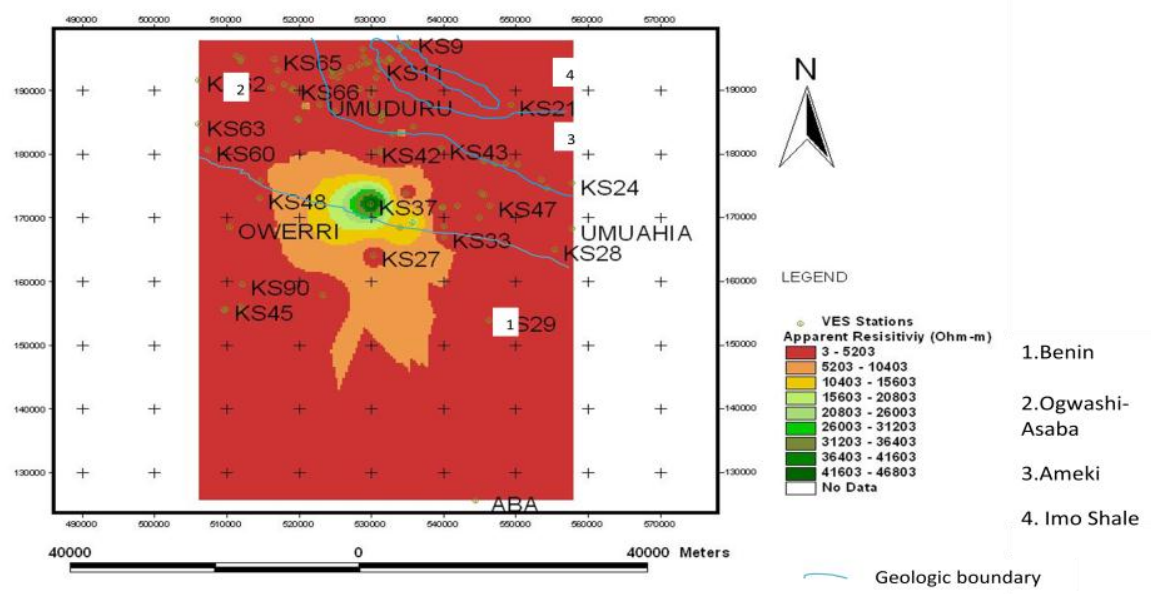

Figure 7: Iso-Resistivity Map for $\mathrm{AB} / 2=300.00 \mathrm{~m}$

\section{Conclusion}

This work provides in graphic detail the resistivity patterns in the study area. The results of the interpretation of the VES data are in close agreement with the lithological information from borehole records.

Over areas in the outcrop surface of the Imo Shale geologic formation, most of the layers consist of shale interspersed with clay, and some sandstone. The presence of clay and shale can impede the downward movement of the contaminant front. Over areas within the Ameki geologic formation, most of the layers consist of shale, clay and sand, and sandstones. Over the areas within the Ogwashi-Asaba formation and the Benin Formation the layers consisted mainly of sand, sandstone, silt and sparsely distributed clay.

\section{References}

[1] B. I. Ijeh , Assessment of Pollution Status and Vulnerability of Water Supply Aquifers in Parts of Imo River Basin, Southeastern Nigeria, doctoral diss., Federal University of Techology Owerri, Nigeria, 2010, 32-42.

[2] S. A. Arabi, J. Raimi, and B. B. M. Dewu, A Geo-electric Survey for Determination of Suitable Sites for Construction of Tube-wells for the proposed Damari Irrigation Scheme in the North-Central Basement Complex, Nigeria.Online Journal of Earth Science, 4(3-4) 2010, 106110 .

[3] N. Sundararajan, R. Nandakumar, N. M. Chary, K. Ramam, and Y. Srinivas, VES and VLF- an application to groundwater exploration, Khammam, India. The LeadingEdge, 2007, 708-716.

[4] J. Raimi, P. Sule and B. B. M. Dewu, A Geoelectric Surveyfor Groundwater: A Case Study in the North Central Basement Complex, Nigeria. Research and Opinion, 2(12), 2010, 158-165.

[5] W, M. Telford, L.P. Geldert and R. E. Sheriff, Applied Geophysics (Cambridge University Press, England 1990) $283-287$.

[6] W. Lowrie, Fundamentals of Geophysics (Cambridge University Press, England, 1997).

[7] W. EWightman, F. Jalinoos, P. Sirles and K. Hanna (2003). Application of Geophysical Methods to Highway Related Problems. Federal Highway Administration, Central Federal Lands Highway Division, Lakewood, CO, Publication No. FHWA-IF-04-021, 2003. http://www.cflhd.gov/resources/agm/

[8] K. O. Uma, Analysis of Transmissivity and Hydraulic Conductivity of Sandy Aquifers of the Imo River Basin, doctoral diss., University of Nigeria, Nsukka, 1986.

[9] Schlumberger, Well evaluation conference Nigeria: Schlumberger Technical Services Inc., 1986.

[10] K. O Uma, An appraisal of the groundwater resources of the Imo River Basin, Nigeria. Journal of Mining and Geology, 25(1), $1989,305-31$. 